\title{
High-protein fraction of 00 type rapeseed meal in broiler nutrition
}

\author{
B.Z. Kamińska, F. Brzóska and B. Skraba \\ Research Institute of Animal Production, \\ Department of Feed Science and Animal Products \\ 32-082 Balice, Poland
}

(Received 26 May 1999; accepted 13 January 2000)

\begin{abstract}
Two batches of a commercial double-low rapeseed meal (RSM) were separated into two fractions on sieves with a mesh diameter of $0.5 \mathrm{~mm}$. In the higher-protein fractions (HP-RSM), which constituted about $35 \%$ of regular RSM (R-RSM), the crude protein level increased by $16 \%$ in the first batch and by $11 \%$ in the second, while crude fibre decreased by 19 and $14 \%$, respectively. The glucosinolate (GLS) content rose from 15.5 to $16.7 \mu \mathrm{M} / \mathrm{g}$ defatted DM in the first batch and from 10 to $11.9 \mu \mathrm{M} / \mathrm{g}$ in the second. In both batches HP-fractions contained less methionine and cystine, while more histidine and phenylalanine than R-RSM.

Two experiments were carried out, each on 1190 commercial broilers allocated to 14 pens on litter. In both experiments the birds were fed starter diets without RSM for the first three weeks. In the grower and finisher diets soyabean meal (SBM) was substituted, partially or totally, by R-RSM or HP-RSM.

In Experiment 1 control broilers were significantly $(\mathrm{P}<0.01)$ heavier than those from the experimental groups, and birds receiving R-RSM were heavier $(\mathrm{P}<0.05)$ on day 48 of life than those given HP-RSM. In Experiment 2 there were no significant differences between the weight of birds receiving SBM or RSM in the diets, however, those given HP-RSM were slightly lighter. In Experiment 2 chickens fed RSM had larger livers $(P<0.05)$ and thyroids $(P<0.01)$ than the control birds.

In both experiments feed conversion efficiency in RSM- fed groups was poorer than in control one, even when the available lysine level was not lower than in the control diet.
\end{abstract}

KEY WORDS: rapeseed meal, dehulling, glucosinolates, thyroid, broilers, chicken

\section{INTRODUCTION}

Rapeseed meal (RSM) is regarded as a valuable protein source for poultry because of its well-balanced amino acid composition. Moreover, RSM offers distinct 
economic advantages to countries where meal from locally grown rape seed can replace imported soyabean meal. Thanks to low glucosinolate (GLS) levels, double-low varieties of RSM can be used to a greater extent in poultry diets than previously. A relatively high level of crude fibre is now thought to be a bigger obstacle than other limiting factors. Although recently developed yellow-seeded „000" varieties have thinner seed coats (Slominski, 1993) and contain less lignin and polyphenols, they are not yet grown on a large scale. Attempts are, therefore, being made to increase the proportion of rapeseed meal in diets for monogastric animals by decreasing those components which limit the availability of nutrients.

According to a new technology, rape seed is peeled at the oil mill before or after oil extraction. In France a new method for peeling rape seed before oil extraction has been developed. As a result of using it, a meal containing $43 \%$ less fibre and $17 \%$ more protein was obtained (Baudet et al., 1988, cited by Chibowska, 1995). In Poland Żernicki (1980) attempted to peel seeds with compressed air in an HEF dehuller-separator. However, the efficiency of the dehulling process was small, with only $40 \%$ of the seeds being peeled in the first and $58 \%$ after the second passage. At the present stage of technology, peeling methods are troublesome and require the use of complex and expensive equipments. It is easier to remove the hulls from rapeseed meal than to peel seeds.

The idea was to divide RSM by mechanical segregation into 2 fractions: one with lower crude fibre and higher protein (HP-RSM) and another with a higher fibre and lower protein levels. The former fraction provide a good feed for poultry, while the latter may be used for ruminants.

The objective of the experiments was to compare the effect of substituting soyabean meal (SBM) by regular RSM or HP-RSM on the performance of broilers.

\section{MATERIAL AND METHODS}

Two batches of commercial double-low, brown-seeded rapeseed meal (RSM) were mechanically segregated by passing through a $0.5 \mathrm{~mm}$ sieve. The fraction named HP-RSM constituted about $1 / 3$ of regular RSM by weight, had less crude fibre and higher protein level, but slightly more glucosinolates (GLS) than regular RSM (Tables 1 and 2).

Experiment 1 was carried out on 1190 Avian broilers kept on litter in 14 pens, each with 85 birds. During the first 3 weeks of life all birds were fed the same starter diet containing $22.5 \%$ crude protein (CP) and $12.3 \mathrm{MJ} \mathrm{ME} / \mathrm{kg}$. The main components of the diet were (\%): maize, 35; wheat, 25 and soyabean meal, 26. At 21 days of life all broilers were weighed and randomly allocated to 7 groups, two replicates (pens) in each. During the next three weeks the birds were fed isoprotein and isoenergetic grower diets containing three levels of R-RSM or HP-RSM, while 
TABLE 1

Chemical analysis of soyabean meal, rapeseed meal and its high-protein fraction, \% DM

\begin{tabular}{lccccccc}
\hline \multicolumn{1}{c}{ Meal } & Experiment & $\begin{array}{c}\text { Dry } \\
\text { matter }\end{array}$ & Ash & $\begin{array}{c}\text { Crude } \\
\text { protein }\end{array}$ & $\begin{array}{c}\text { Ether } \\
\text { extract }\end{array}$ & $\begin{array}{c}\text { Crude } \\
\text { fibre }\end{array}$ & $\begin{array}{c}\text { N-free } \\
\text { extractives }\end{array}$ \\
\hline $\begin{array}{l}\text { Soyabean } \\
\text { (SBM) }\end{array}$ & 1 & 88.16 & 7.30 & 47.80 & 2.04 & 10.00 & 32.86 \\
& 2 & 87.90 & 6.98 & 51.20 & 1.98 & 11.34 & 28.50 \\
Regular rapeseed & 1 & 86.96 & 7.72 & 38.87 & 3.70 & 18.08 & 31.63 \\
(R-RSM) & 2 & 88.69 & 7.69 & 38.90 & 2.99 & 15.69 & 33.83 \\
& 1 & 86.29 & 8.30 & 45.22 & 1.84 & 14.60 & 30.04 \\
High-protein rapeseed & 1 & 89.11 & 8.14 & 44.10 & 2.32 & 13.54 & 31.90 \\
(HP-RSM) & 2 & & & & & &
\end{tabular}

TABLE 2

Glucosinolate content of rapeseed meal and its high-protein fraction, $\mu \mathrm{M} / \mathrm{g}$ deffated DM

\begin{tabular}{|c|c|c|c|c|c|c|c|}
\hline $\mathrm{RMS}^{1}$ & Experiment & Progoitrin & $\begin{array}{l}\text { Gluco- } \\
\text { napin }\end{array}$ & $\begin{array}{c}\text { Gluco- } \\
\text { brassicanapin }\end{array}$ & $\begin{array}{c}\text { Gluco- } \\
\text { napoleiferin }\end{array}$ & $\begin{array}{l}\text { 4-hydroxy- } \\
\text { glucobrassicin }\end{array}$ & $\begin{array}{l}\text { Total } \\
\text { GLS }\end{array}$ \\
\hline \multirow[t]{2}{*}{ R-RSM } & 1 & 9.7 & 4.3 & 0.84 & 0.48 & 0.12 & 15.49 \\
\hline & 2 & 6.4 & 2.8 & 0.47 & 0.23 & 0.07 & 9.99 \\
\hline \multirow[t]{2}{*}{ HP-RSM } & 1 & 10.5 & 4.6 & 0.83 & 0.47 & 0.22 & 16.69 \\
\hline & 2 & 7.5 & 3.3 & 0.58 & 0.34 & 0.10 & 11.86 \\
\hline
\end{tabular}

1 see Table 1

the control group was fed a diet with $20 \%$ SBM. During the final week three finisher diets were fed (Table 4). The dietary protein level was balanced by meat meal and meat-and-bone meal, the energy level by blended fat.

Experiment 2 was carried out on 1190 Starbro broilers allocated to 14 pens of 85 birds in each. Up to 21 days of life all broilers were fed a starter diet containing $21.5 \% \mathrm{CP}$ and $12.3 \mathrm{MJ} \mathrm{ME} / \mathrm{kg}$, with (\%): maize, 30; wheat, 29 and SBM, 27, as the main components. From 21 to 48 days of life 7 groups were fed grower diets containing $20 \% \mathrm{CP}$ and $13.3 \mathrm{MJ} \mathrm{ME} / \mathrm{kg}$ while other 7 groups were fed diets containing $18.5 \% \mathrm{CP}$ and $12.5 \mathrm{MJ} \mathrm{ME} / \mathrm{kg}$ (Table 5).

All broilers were individually weighed in Experiment 1 at 3,6 and 7 weeks, in Experiment 2 at 3 and 7 weeks of age. At the end of the experiments the birds were checked for sex. Four males and four females of a weight close to the mean for the group and sex were chosen from each of seven groups in Experiment 1 and from ten groups in Experiment 2 for carcass analysis. During dissection fatty tissue was taken off if found on the breast musclc. 
In RSM and HP-RSM dry matter, nitrogen, fat, ash and crude fibre were analyzed using standard methods (AOAC, 1990). The amino acid content, excluding tryptophan, was determined on a Carlo Erba automatic analyzer. Glucosinolate content was analyzed by HPLC according to the ISO-9167 method (1991).

The results were subjected to ANOVA (GLM) analysis (SAS Institute, 1985).

\section{RESULTS}

HP-RSMs contained more crude protein and less crude fibre than the RSM by 4-5 and 1-2.4 percentage units, respectively (Table 1). HP-RSM from the first batch contained slightly more crude protein and crude fibre but less crude fat than that from the second batch. Total glucosinolate level was slightly higher in HPRSM than in RSM (Table 2).

In both batches HP-RSM protein contained less methionine and cystine while more histidine and phenylalanine than RSM (Table 3).

Experiment 1. Chickens receiving diets containing RSM were at 42 days of life significantly lighter $(\mathrm{P}<0.01)$ than birds fed the control diet, but there were no significant differences between birds fed diets with R-RSM or HP-RSM (Table 6). At the age of 48 days broilers offered R-RSM were heavier $(\mathrm{P}<0.05)$ than those fed diets with HP-RSM but lighter by $3-5 \%$, respectively, than control ones.

TABLE 3

Amino acid content of the regular and HP fraction of rapeseed meal, g/16 g N

\begin{tabular}{lccccc}
\hline \multirow{2}{*}{ amino } & \multicolumn{2}{c}{ R-RSM $^{\prime}$} & & \multicolumn{2}{c}{ HP-RSM $^{\prime}$} \\
\cline { 2 - 4 } \cline { 5 - 6 } & \multicolumn{2}{c}{ Experiment } & 2 & 1 & \multicolumn{2}{c}{ Experiment } \\
\hline Lys & 5.85 & 5.60 & 5.99 & 5.44 \\
Met & 2.41 & 2.85 & 2.20 & 1.88 \\
Cys & 2.84 & 3.57 & & 2.10 & 2.64 \\
Thr & 5.40 & 4.98 & & 4.86 & 4.92 \\
Val & 5.36 & 4.92 & & 5.42 & 5.02 \\
Arg & 5.95 & 6.19 & & 6.62 & 5.74 \\
Gly & 5.80 & 5.38 & & 5.50 & 5.45 \\
Ser & 4.47 & 4.77 & & 4.17 & 4.73 \\
His & 2.80 & 2.77 & & 3.48 & 3.83 \\
Ile & 4.00 & 3.73 & & 4.66 & 3.84 \\
Leu & 7.18 & 7.45 & & 7.79 & 7.39 \\
Phe & 4.66 & 4.24 & & 5.13 & 5.56 \\
Tyr & 3.54 & 2.63 & & 3.34 & 3.93 \\
\hline
\end{tabular}

I see Table 1 


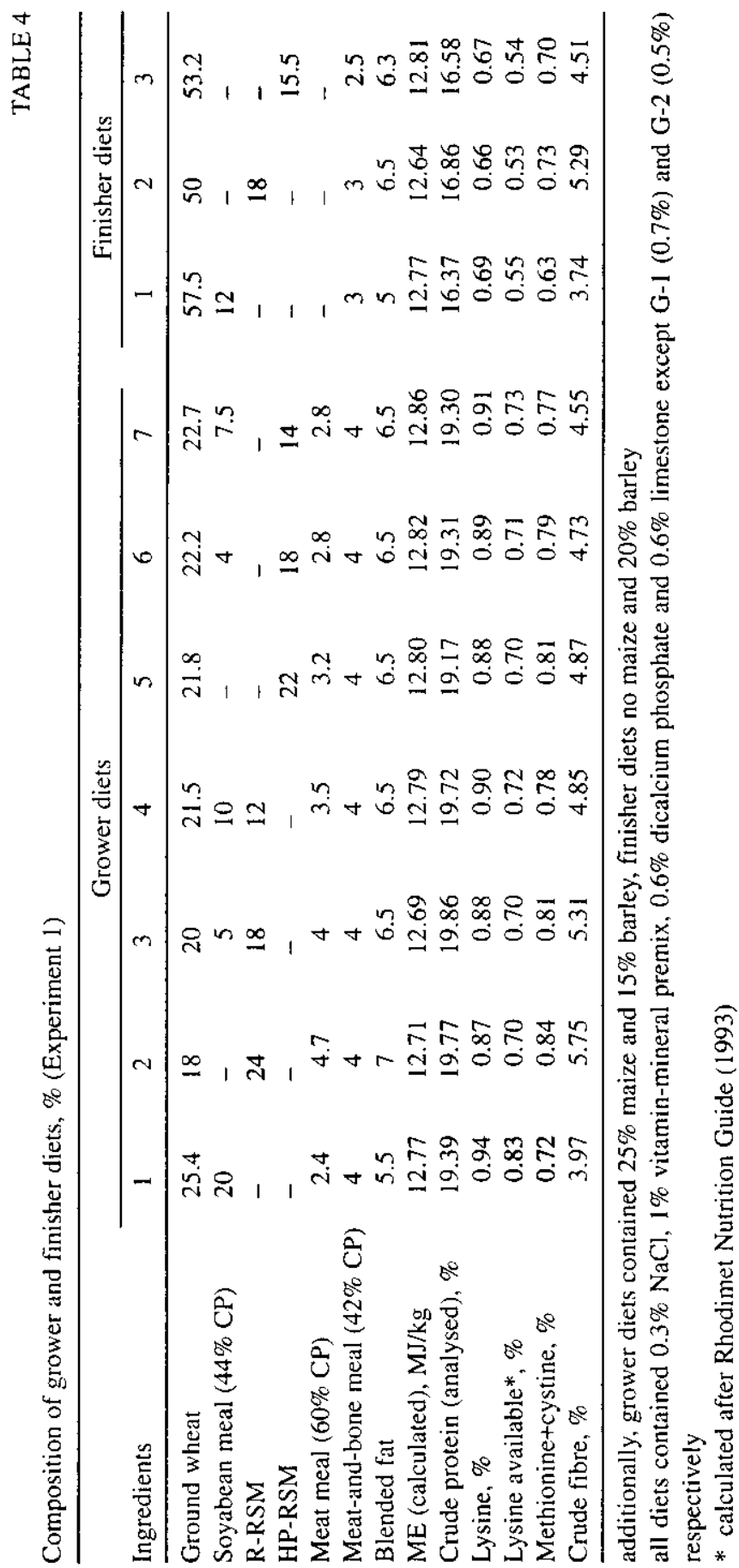


最

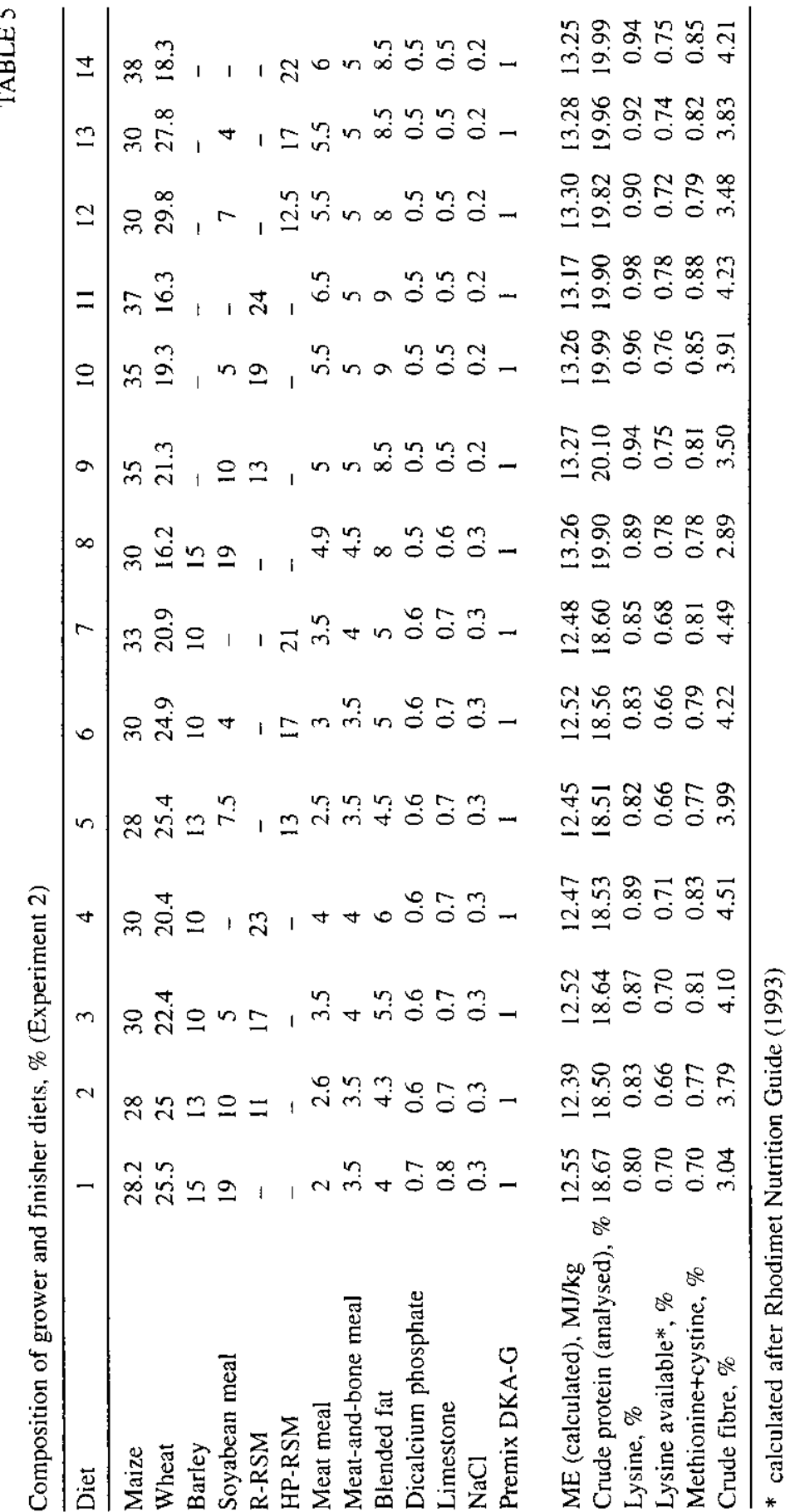


Feed conversion efficiency in groups fed diets containing RSM was poorer than in the control group in the grower period, but not in the finisher period (Table 6).

Carcasses of chickens receiving diets with R-RSM contained more breast muscle and less fat $(\mathrm{P}<0.01)$ than the control birds (Table 7). Relative liver weight of the birds fed diets with RSM or HP-RSM was not greater than that of control ones.

Experiment 2. Dietary protein level, type or level of meal had no significant effect on final body weight of chickens (Table 8). However, feed efficiency was better in the control groups than groups fed R-RSM or HP-RSM.

Birds fed diets with R-RSM or HP-RSM had larger livers $(P<0.05)$, expressed as percent of carcass, than those of the control groups (Table 9). However, there were very small differences in liver weight between birds receiving $21-24 \%$ or 11-13\% RSM (Table 9).

Relative weight of thyroid glands was much smaller in the control birds $(8.4 \mathrm{mg} / 100 \mathrm{~g} \mathrm{BW})$ than in broilers receiving $11-13 \% \mathrm{R}-\mathrm{RSM}(10 \mathrm{mg})$ or $23-24 \%$ R-RSM (12.8 mg). Statistically, highly significant differences were also observed between thyroid size of birds given R-RSM and HP-RSM (11.4 mg vs $13.2 \mathrm{mg} /$ $100 \mathrm{~g} \mathrm{BW}$ ).

TABLE 6 The mean body weight of broilers at 6 and 7 weeks of age and feed efficiency, $\mathrm{kg}$ feed $/ \mathrm{kg}$ gain (Experiment 1)

\begin{tabular}{|c|c|c|c|c|c|}
\hline \multirow[t]{2}{*}{ Group } & \multirow{2}{*}{$\begin{array}{c}\text { Dietary meal } \\
\text { level }\end{array}$} & \multicolumn{2}{|c|}{ Body weight, g } & \multicolumn{2}{|c|}{ Feed efficiency } \\
\hline & & 42 days & 48 days & $22-42$ days & $42-48$ days \\
\hline 1 & $20 \%$ SBM & $1699^{A}$ & $1987^{\mathrm{A}}$ & 2.18 & 3.10 \\
\hline 2 & $24 \%$ R-RSM & 1572 & 1930 & 2.31 & 3.08 \\
\hline 3 & $18 \% \mathrm{R} \cdot \mathrm{RSM}$ & 1547 & $1901^{\mathrm{B}}$ & 2.33 & 3.06 \\
\hline 4 & $12 \%$ R-RSM & 1527 & 1931 & 2.30 & 3.01 \\
\hline 5 & $22 \%$ HP-RSM & 1526 & $1882^{\mathrm{B}}$ & 2.36 & 3.11 \\
\hline 6 & $18 \%$ HP-RSM & 1534 & 1920 & 2.35 & 3.09 \\
\hline 7 & $14 \%$ HP-RSM & 1529 & $1863^{\mathrm{B}}$ & 2.37 & 3.12 \\
\hline \multirow{2}{*}{\multicolumn{2}{|c|}{ Pooled SEM }} & 53.1 & 33.1 & & \\
\hline & & \multicolumn{2}{|c|}{ Probability } & & \\
\hline \multicolumn{6}{|c|}{ Source of variation } \\
\hline \multicolumn{2}{|c|}{ type of RSM } & 0.1988 & 0.0076 & & \\
\hline \multicolumn{2}{|c|}{$\operatorname{sex}$} & 0.0001 & 0.0001 & & \\
\hline \multicolumn{2}{|c|}{ interaction } & 0.9578 & 0.5268 & & \\
\hline \multicolumn{6}{|c|}{ Main effect means } \\
\hline \multicolumn{2}{|c|}{ R-RSM } & $1548^{\wedge}$ & $1921^{a}$ & & \\
\hline \multicolumn{2}{|c|}{ HP-RSM } & $1530^{\wedge}$ & $1889^{\circ}$ & & \\
\hline \multicolumn{2}{|c|}{ Males } & $1698^{\wedge}$ & $2044^{A}$ & & \\
\hline \multicolumn{2}{|c|}{ Females } & $1449^{\mathrm{B}}$ & $1804^{\mathrm{B}}$ & & \\
\hline
\end{tabular}

ab $\mathrm{P}<0.05 ;{ }^{\mathrm{AB}} \mathrm{P}<0.01$ 
TABLE 7

Carcass yield, \% of live body weight, and skin, muscles and fat content in carcass, \% (Experiment 1 )

\begin{tabular}{lcccccc}
\hline $\begin{array}{l}\text { Dietary meal } \\
\text { and level, \% }\end{array}$ & $\begin{array}{c}\text { Carcass } \\
\text { yield, \% }\end{array}$ & Liver & $\begin{array}{c}\text { Skin with } \\
\text { subcutaneus fat }\end{array}$ & $\begin{array}{c}\text { Breast } \\
\text { muscles }\end{array}$ & $\begin{array}{c}\text { Drumstick } \\
\text { muscles }\end{array}$ & $\begin{array}{c}\text { Abdominal } \\
\text { fat pads }\end{array}$ \\
\hline SBM, 20 & 72.1 & 3.20 & 11.7 & 18.8 & 9.6 & 4.7 \\
R-RSM, 24 & 72.8 & 3.29 & 10.8 & 19.7 & 9.5 & 4.0 \\
R-RSM, 18 & 73.7 & 2.89 & 10.2 & 20.7 & 9.6 & 4.3 \\
R-RSM, 12 & 72.7 & 3.13 & 10.2 & 20.5 & 9.6 & 4.5 \\
H-RSM, 22 & 73.1 & 3.12 & 10.3 & 19.5 & 9.9 & 4.6 \\
H-RSM, 18 & 71.9 & 2.88 & 9.6 & 20.4 & 10.2 & 3.8 \\
H-RSM, 14 & 71.8 & 3.42 & 10.0 & 19.6 & 9.5 & 4.1 \\
Pooled SEM & 0.52 & 0.14 & 0.32 & 0.55 & 0.26 & 0.19 \\
& & & Main effect means & & \\
SBM & 72.06 & 3.20 & $11.70^{\mathrm{A}}$ & $18.85^{\mathrm{B}}$ & 9.63 & $4.71^{\mathrm{a}}$ \\
R-RSM & 73.11 & 3.10 & $10.40^{\mathrm{B}}$ & $20.30^{\mathrm{A}}$ & 9.57 & $4.27^{\mathrm{B}}$ \\
HP-RSM & 72.32 & 3.14 & $9.98^{\mathrm{B}}$ & $19.82^{\mathrm{AB}}$ & 9.91 & $4.17^{\mathrm{b}}$ \\
\hline
\end{tabular}

ab $\mathrm{P}<0.05 ;{ }^{\mathrm{AB}} \mathrm{P}<0.01$

\section{DISCUSSION}

Sieving RSM to decrease the crude fibre content proved not to be a very efficient procedure. Although dark-seeded rape contains no more than $22-25 \%$ hulls by weight (Mitaru et al.,1983; Smulikowska et al., 1998), the HP-RSM fraction obtained by us constituted only $35 \%$ of the initial weight. In the experiment of Chibowska et al. (1993) sieving on 3 sieves with various mesh diameter resulted in achieving HP-fraction which constituted $50 \%$ of RSM. With regard to technological procedures, peeling before oil extraction may be more important. Fraction rich in hulls may be fed to ruminants (Keller et al., 1996).

In the first batch of HP-RSM, crude fibre decreased by $19 \%$ and in the second by $14 \%$, while the protein level increased by 16 and $11 \%$, respectively. In the experiment of Shires et al. (1983), quoted by Chibowska (1995) separation of hulls from RSM on sieves with a mesh diameter of $0.323 \mathrm{~mm}$ resulted in decrease of fibre content by $43 \%$, but the amount of protein increased only by $8 \%$. When separating RSM on a sieve with a mesh diameter of $0.4 \mathrm{~mm}$ Żernicki (1978) achieved a similar reduction of crude fibre level - from 15.6 to $9 \%$, i.e. by $42 \%$. In the experiment of Chibowska et al. (1993) the protein level increased from 36.2 to $42 \%$ DM, i.e. by $16 \%$, while crude fibre decreased by $26 \%$ in the fraction which constituted $50 \%$ of RSM.

In the experiment of Seth and Clandinin (1973), the level of lysine in the lowhull fraction of Bronowski RSM was the same as in our experiment and did not 
TABLE 8

Mean body weight of broilers at 48 days and feed efficiency, $\mathrm{kg}$ feed $/ \mathrm{kg}$ gain (Experiment 2)

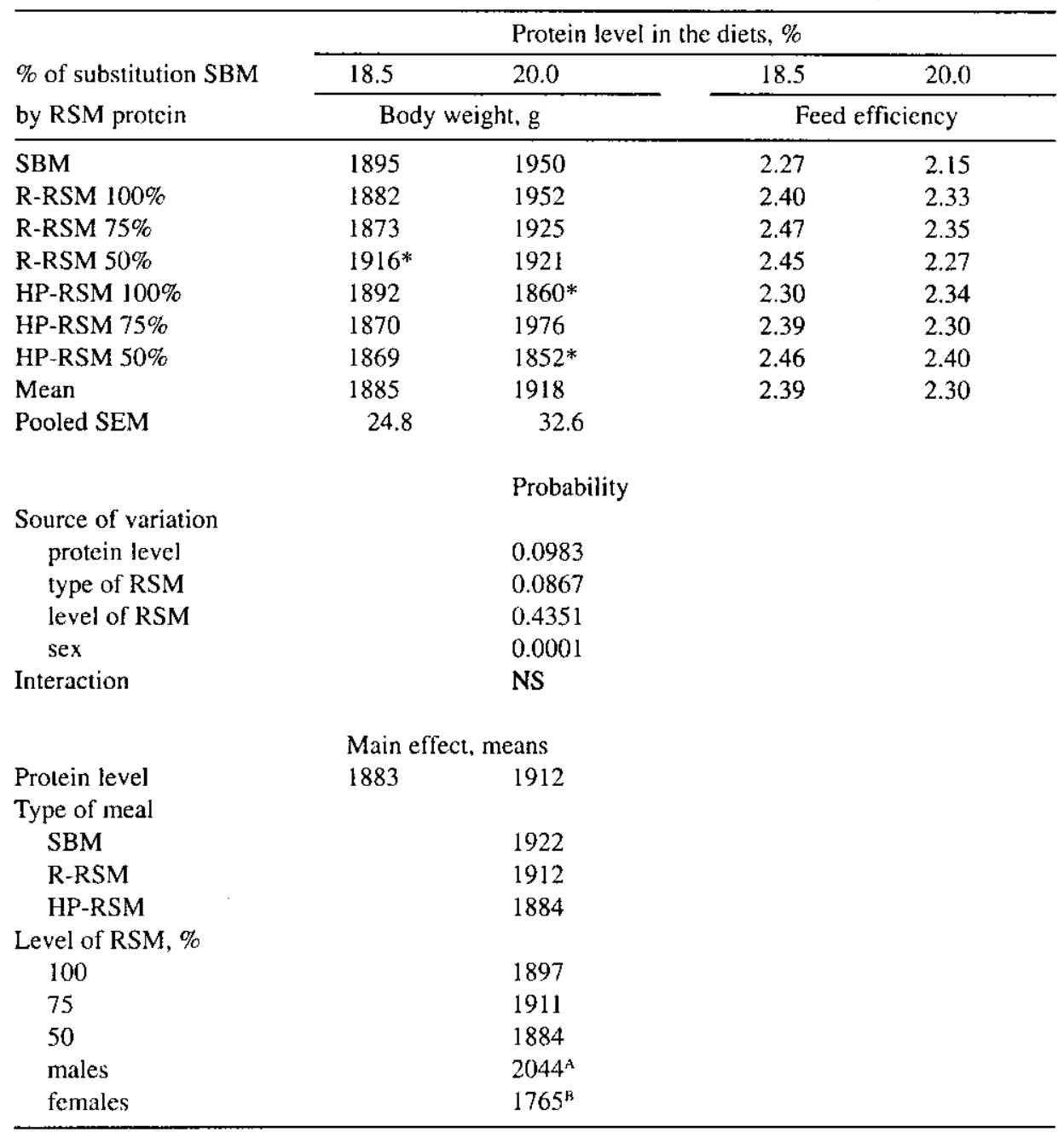

* differed from the other within a column at $\mathrm{P}<0.05$, Ав $\mathrm{P}<0.01$

differ from the level in R-RSM. However, they found B. campestris and B. napus to contain significantly more lysine in the low-hull fraction than in regular RSM. The low-hull fraction separated from three varieties of RSM by Seth and Clandinin (1973) contained almost the same level of sulphur amino acids as regular RSM. 
TABLE 9

Carcass yield, \% of live body weight, thyroids ( $\mathrm{mg} / 100 \mathrm{~g} \mathrm{BW}$ ) and liver, skin, muscles and abdominal fat content in carcass, \% (Experiment 2)

\begin{tabular}{|c|c|c|c|c|c|c|c|c|}
\hline \multirow{2}{*}{$\begin{array}{l}\text { Meal level } \\
\text { in the diet }\end{array}$} & \multirow{2}{*}{$\begin{array}{l}\text { Dietary } \\
\text { crude } \\
\text { protein, } \\
\%\end{array}$} & \multirow{2}{*}{$\begin{array}{l}\text { Carcass } \\
\text { yield, \% }\end{array}$} & \multirow{2}{*}{$\begin{array}{l}\text { Thyroid } \\
\text { glands }\end{array}$} & \multirow[t]{2}{*}{ Liver } & \multirow{2}{*}{$\begin{array}{c}\text { Skin with } \\
\text { subcutaneous } \\
\text { fat }^{1}\end{array}$} & \multicolumn{2}{|c|}{ Muscles } & \multirow{2}{*}{$\begin{array}{c}\text { Abdominal } \\
\text { fat pads }\end{array}$} \\
\hline & & & & & & breast & drumstick & \\
\hline $19 \%$ SBM & 18.5 & 72.7 & 8.1 & 2.51 & 9.81 & 22.13 & 8.92 & 2.22 \\
\hline $19 \%$ SBM & 20.0 & 70.7 & 8.7 & 2.43 & 9.92 & 22.80 & 13.35 & 2.04 \\
\hline $23 \%$ R-RSM & 18.5 & 69.3 & 12.9 & 2.90 & 9.17 & 22.12 & 9.71 & 1.98 \\
\hline $24 \%$ R-RSM & 20.0 & 70.5 & 12.7 & 2.78 & 10.15 & 21.26 & 9.61 & 2.24 \\
\hline $21 \%$ HP-RSM & 18.5 & 70.2 & 13.0 & 2.78 & 9.70 & 21.63 & 9.60 & 2.15 \\
\hline $22 \%$ HP-RSM & 20.0 & 69.8 & 14.6 & 2.72 & 9.92 & 23.11 & 9.62 & 2.32 \\
\hline $11 \%$ R-RSM & 18.5 & 70.5 & 8.9 & 2.81 & 9.80 & 22.89 & 9.68 & 2.31 \\
\hline $13 \%$ R-RSM & 20.0 & 68.9 & 11.1 & 2.66 & 9.68 & 20.92 & 9.97 & 1.75 \\
\hline 13\% HP-RSM & 18.5 & 69.5 & 13.5 & 2.84 & 9.90 & 21.11 & 9.53 & 2.66 \\
\hline $12.5 \%$ HP-RSM & 20.0 & 69.2 & 11.6 & 2.48 & 9.91 & 21.60 & 10.11 & 2.11 \\
\hline \multirow[t]{2}{*}{ Pooled SEM } & & 0.50 & 1.0 & 0.12 & 0.35 & 0.50 & 0.30 & 0.26 \\
\hline & \multicolumn{8}{|c|}{ Main effect, means } \\
\hline SBM & & $71.4^{\mathrm{a}}$ & $8.4^{C}$ & $2.47^{\mathrm{b}}$ & 9.86 & 22.54 & 9.83 & 2.13 \\
\hline R-RSM & & $69.8^{\mathrm{b}}$ & $11.4^{\mathrm{B}}$ & $2.79^{\mathrm{a}}$ & 9.79 & 21.86 & 9.74 & 2.07 \\
\hline HP-RSM & & $69.9^{b}$ & $13.2^{\mathrm{A}}$ & $2.72^{a}$ & 9.89 & 22.01 & 9.79 & 2.30 \\
\hline
\end{tabular}

1 skin from the whole carcass except of the wings

means bearning superscript $\mathrm{A}$ or $\mathrm{B}$ differ significantly within a column, capital letters $\mathrm{P}<0.01$, small letters $\mathrm{P}<0.05$

Rape seeds contain aliphatic glucosinolates (progoitrin, gluconapin, glucobrassicanapin and gluconapoleiferin) and small amounts of indole type glucosinolates (4-OH-glucobrassicin). Vinyloxazolidinethione (VOT), the product of progoitrin hydrolysis, limits the uptake of iodine from blood and inhibits the reactions of thyrosine iodination resulting in hypothyroidism, while the indole derivatives inactivate liver enzymes.

In the first batch, HP-RSM contained $8 \%$ more GLS than regular RSM, and $16 \%$ more in the second batch. This is understandable, for the majority of GLS is found in the kernel, so dehulling results in an increased GLS concentration in the remaining fraction. 
In the first batch of RSM the glucosinolate level $(15.5 \mu \mathrm{M} / \mathrm{g}$ defatted DM) was similar to that found by Korol et al. (1994) in the Ceres variety. In the second batch it was lower $(9.99 \mu \mathrm{M} / \mathrm{g})$, similar to the level of aliphatic GLS $(9 \mu \mathrm{M} / \mathrm{g})$ in the experiment of Kinal et al. (1990). These levels of GLS are lower than the upper permissible content in double-low rapeseed meal, i.e. $20 \mu \mathrm{M} / \mathrm{g}$ defatted DM (Koreleski, 1993).

In the experiment of Kinal et al. (1990) the inclusion of 10\% RSM in the starter and $15 \%$ in the grower diet resulted in an increase in thyroid weight from 9.5 in the control group to $18 \mathrm{mg} / 100 \mathrm{~g} \mathrm{BW}$. In our experiment thyroids were much smaller even when broilers were offered grower diets containing up to $24 \%$ RSM. Smulikowska et al. (1998), when giving broilers $20 \%$ RSM containing $21 \mu \mathrm{M}$ GLS/g, found that in 22-day-old cockerels the thyroid was only slightly heavier than in controls ( 8.4 vs $7.3 \mathrm{mg} / 100 \mathrm{~g} \mathrm{BW}$ ). Matsumoto and Akiba (1979) found that despite the enlargement of thyroid glands as a result of GLS intake, thyroid function in chickens was kept at a fairly good level.

Gawęcki et al. (1983) reported that various amounts of VOT and ITC consumed by birds gave a similar reaction and suggested that a strong negative reaction occurs when the intake threshold of these components has been exceeded. This is in agreement with the results of our experiment where no differences in broiler performance were found regardless of the level of RSM in the diet. Diets of high or moderate level of RSM had a similar effect on the liver size.

Because of lower digestibility of rapeseed meal protein and a slightly worse composition of exogenous amino acids, SBM was not replaced with RSM in the starter diets of our experiments. Early in life chickens grow very quickly and are particularly sensitive to feed quality.

In Experiment 1 the control diet contained $0.83 \%$ and the R-RMS or HP-RSM diets $0.70-0.73 \%$ digestible lysine calculated according to Rhodimet Nutrition Guide (1993). In Experiment 2 the content was 0.78 or $0.70 \%$ in the control diets and $0.78-0.66 \%$ in the R-RMS or HP-RSM diets, depending on the crude protein level of the diet. In Experiment 1 replacing SBM, partly or completely, with RSM had an adverse effect on body weight gains of chickens, possibly because of the insufficient amount of digestible lysine.

In Experiment 2 there were no differences between broilers receiving the control SBM diet or various levels of R-RSM, only those given HP-RSM were slightly lighter. In the experiment of Simbaya and Slominski (1992) growth of White Leghorn cockerels was not improved on dehulled canola meal relative to the regular meal from brown or yellow rape seed.

In the experiments of Smulikowska et al. (1991) substitution by weight of SBM with RSM decreased crude protein in the diet from 187 to $168 \mathrm{~g} / \mathrm{kg}$ and the lysine level from 0.92 to $0.72 \%$ ( 0.76 vs $0.62 \%$ available lysine). As a result, the body weight of 4-week-old broilers was $21 \%$ lower and feed efficiency was $8 \%$ poorer. 
Supplementing lysine up to $0.92 \%$ of the diet increased body weight and improved feed efficiency compared with the control group. In our experiments feed efficiency was not improved, even when the lysine level was elevated.

In the experiment of Koreleski et al. (1992) 8-week-old broilers fed grower/ finisher diets containing $15 \%$ double-low RSM weighed over $170 \mathrm{~g}$ less than those from the control group. There was also a significant difference in FCR ( 2.54 vs 3.03 ) in the period of 22-56 days of age, however the diets were not isoenergetic.

Bouchardeau (1972) found that broilers fed diets with RSM were less fatty. Also in the experiment of Koreleski et al. (1992), carcasses of broilers fed a diet with $15 \%$ RSM had slightly less abdominal fat than those of the control birds (1.4 vs $2.5 \%$ ). This is in agreement with the results achieved by us in Experiment 1, but in Experiment 2 broilers fed the RSM diet had as much fat as those fed SBM diets.

\section{CONCLUSIONS}

Substitution of SBM by regular RSM or its fraction with higher protein and lower fibre content did not decrease the weight gain of broiler chicken when the available lysine level was maintained in the diet. Feed conversion efficiency, however, was poorer.

The HP-fraction containing more glucosinolates led to a greater enlargement of thyroid glands than did regular RSM. There were no differences in liver size of broilers fed R-RSM or HP-RSM.

Despite a slight decrease in feed efficiency, rapeseed meal can be regarded as a good component of a grower diet. Of great significance is the much lower price of rapeseed meal compared to soyabean meal and the fact that RSM did not lower the quality of the carcass.

\section{REFERENCES}

AOAC. 1990. Official Methods of Analysis of the Association of Analytical Chemist. 15th Edition. Washington, DC

Bouchardeau A., 1972. Dans quelles conditions le tourteau de colza convient-il aux volailles? Rev. Elev. Ann. 27, No. 304, 47-53

Chibowska M., 1995. The energy value of low glucosinolate rapeseed meal as affected by fibre and fat content - model experiments on chicks. Ph.D Thesis, The Kielanowski Institute of Animal Physiology and Nutrition, Jabłonna (Poland)

Chibowska M., Pastuszewska B., Smulikowska S., Alloui O., 1993. Chemical and energy value of double low rapeseed meal fraction for chicken (in Polish). Post. Nauk rol. 40 (6), 167-172

Gawçcki K., Rutkowski A., Lipińska H., 1983. An attempt at using oilmeal from low-glucosinolate rapesced Start 00 instead of soya bean meal in broiler diets (in Polish). Rocz. Nauk. Zoot. 10, $117-126$ 
ISO-9167-1, Polish Standard, 1991. HPLC method of Glucosinolates Determination (in Polish)

Keller T., Kracht W., Dänicke S., Jeroch H., 1996. A note on the chemical composition of rape seed hulls and their feeding value for ruminants. J. Anim. Feed Sci. 5, 127-134

Kinal S., Fritz Z., Jarosz L., Schleicher A., 1990. Rape seeds, partly deffated seeds and rapeseed oil meal from variety Jantar in the feeding of broilers (in Polish). Rocz. Nauk. Zoot., Monogr. Rozpr. No 28, 251-260

Koreleski J., 1993. Plant defensive substances in poultry feeds (in Polish). Pol. Drob. 2 (12), 6-8

Koreleski J., Kubicz M.. Ernest T., Kosmala I., Zegarek Z., 1992. The limit levels of home-grown grains, legume seeds and rape-seed oil meal in grower-finisher feed-mixlures for broiler chicks (in Polish). Rocz. Nauk. Zoot. 19, 143-159

Korol W., Jaśkiewicz T., Bartuzi G., Bogusz G., Nieściór H., Grabowski C., Mojek E., 1994. Chemical composition of rape seed from low glucosinolate varieties grown in Poland. J. Anim. Feed Sci. 3, 57-64

Matsumoto T., Akiba Y., 1979. Effect of rapeseed meal on growth and thyroid function of broilers chicks. Jpn. Poultry Sci. 16, 49-51

Mitaru B. N., Blair R., Bell J.M., Reichert R., 1983. Effect of canola hulls on growth, feed efficiency, and protein and energy utilization in broiler chickens. Can. J. Anim. Sci. 63, 655-662

Rhodimet $^{\mathrm{TM}}$ Nutrition Guide, 1993. Feed ingredients formulation in digestible amino acids. 2nd Edition. Rhône-Poulenc Animal Nutrition

Seth P.C.C.. Clandinin D.R., 1973. Metabolisable energy value and composition of rapeseed meal and of fractions derived therefrom by air-classification. Brit. Poultry Sci. 14, 499-505

Simbaya J., Slominski B., Campbell L.D., 1992. Nutritive quality of dehulled and yellow-seeded canola meals for poultry. Poultry Sci. 71, Suppl. 1, 14 (Abstr.)

Slominski B.A.,1993. Canola meal quality characteristics. Proceedings of Maryland Nutrition Conference for Feed Manufacturers, The University of Maryland (USA), pp. 18-30

Smulikowska S., Chibowska M., Wiśniewska J., 1991. Effect of supplementing with lysine and methionine of concentrate mixtures with rapeseed meal 00 on performance of broiler chickens (in Polish). Prz. hod., Zesz. Nauk. No. 2, 140-149

Snulikowska S., Pastuszewska B., Ochtabińska A., Mieczkowska A., 1998. Composition and nutritional value for chickens and rats of seeds, cake and solvent meal from low-glucosinolate yellow-seeded spring rape and dark-seeded winter rape. J. Anim. Feed Sci. 7, 415-428

Statistical Analysis System User's Guide: Statistics, 1985. SAS Institute Inc., Cary, NC

Żernicki W., 1978. Effect of some methods of separating various meals on improving their nutritional values (in Polish). Ph.D.Thesis, Central Laboratory of Feed Industry, Lublin (Poland)

Żernicki W., 1980. Effect of the different dehulling parameters of the selected raw materials on the chemical composition and physical propertics of the obtained fractions. Part I. Studies on dchulling of the horse bean seeds and rape seeds (in Polish). Biul. inf. Przem. Pasz. 19 (2), $10-22$ 


\section{STRESZCZENIE}

Frakcja śruty rzepakowej 00 o podwyższonej zawartości bialka w żywieniu kurcząt broilerów

Dwie partie handlowej poekstrakcyjnej śruty rzepakowej 00 rozdzielono na dwie frakcje na sicie o średnicy oczek $0,5 \mathrm{~mm}$. Frakcja o cząstkach mniejszych niż $0,5 \mathrm{~mm}$ (HP-RSM) stanowiła około $35 \%$ materiału wyjściowego. Zawierała ona mniej włókna surowego o 14 i 19\%, a więcej białka ogólnego o 16 i 11\% i glukozynolanów o 8 i 19\% (odpowiednio w 1 i 2 partii) niż wyjściowa śruta.

Przeprowadzono 2 doświadczenia, każde na 1190 kurczętach brojlerach rozmieszczonych w 14 kojcach po 85 ptaków w każdym. W obydwóch doświadczeniach przez pierwsze 3 tygodnie ptaki żywiono mieszanką starter bez śruty rzepakowej. W mieszankach grower i finiszer śrutę sojową zastępowano, częściowo lub całkowicie, śrutą rzepakową lub HP-RSM.

W doświadczeniu 1 w 48 dniu życia masa ciała kurcząt z grupy kontrolnej była największa $(\mathrm{P}<0,01)$, a kurcząt otrzymujących HP-RSM wickssza $(\mathrm{P}<0,05)$ niż kurcząt żywionych normalną śrutą rzepakową. W doświadczeniu 2 nie stwierdzono istotnych różnic w końcowej masie ciała kurcząt, lecz w grupie otrzymującej HP-RSM była ona najniższa. W doświadczeniu 2 masa wątroby i tarczycy kurcząt żywionych śrutą rzepakową lub HP-RSM byla większa $(\mathrm{P}<0,05$ i $\mathrm{P}<0,01)$ niż kurcząt kontrolnych.

W obydwóch doświadczeniach wykorzystanie paszy było gorsze w grupach żywionych śrutą rzepakową lub HP-RSM niż w grupie kontrolnej, nawet gdy zawartość lizyny dostępnej była podobna. 